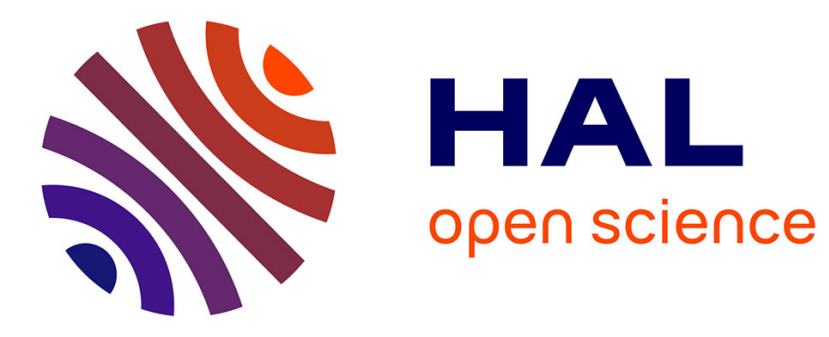

\title{
Access to Stable Quaternary Phosphiranium Salts by P-Alkylation and P-Arylation of Phosphiranes
}

\author{
Julien Gasnot, Clément Botella, Sébastien Comesse, Sami Lakhdar, Carole
} Alayrac, Annie-Claude Gaumont, Vincent Dalla, Catherine Taillier

\section{- To cite this version:}

Julien Gasnot, Clément Botella, Sébastien Comesse, Sami Lakhdar, Carole Alayrac, et al.. Access to Stable Quaternary Phosphiranium Salts by P-Alkylation and P-Arylation of Phosphiranes. SYNLETT, 2020, 31 (09), pp.883-888. 10.1055/s-0040-1708000 . hal-02899695

\section{HAL Id: hal-02899695}

\section{https://hal-normandie-univ.archives-ouvertes.fr/hal-02899695}

Submitted on 15 Dec 2020

HAL is a multi-disciplinary open access archive for the deposit and dissemination of scientific research documents, whether they are published or not. The documents may come from teaching and research institutions in France or abroad, or from public or private research centers.
L'archive ouverte pluridisciplinaire HAL, est destinée au dépôt et à la diffusion de documents scientifiques de niveau recherche, publiés ou non, émanant des établissements d'enseignement et de recherche français ou étrangers, des laboratoires publics ou privés. 


\title{
Access to Stable Quaternary Phosphiranium Salts by $\mathbf{P}$ Alkylation and $\mathbf{P}$ Arylation of Phosphiranes
}

\author{
Julien Gasnot, ${ }^{\mathrm{a}}$ Clément Botella, ${ }^{\mathrm{a}}$ Sébastien Comesse, ${ }^{\mathrm{a}}$ Sami Lakhdar, ${ }^{\mathrm{b}}$ Carole Alayrac, ${ }^{\mathrm{b}}$ Annie-Claude \\ Gaumont, ${ }^{\mathrm{b}}$ Vincent Dalla, ${ }^{\mathrm{a}^{*}}$ Catherine Taillier ${ }^{\mathrm{a}^{*}}$ \\ ${ }^{a}$ Normandie Univ., URCOM, UNIHAVRE, FR3032, EA 3221, 25 rue P. Lebon, BP 540, 76058 Le Havre (France). \\ *vincent.dalla@univ-lehavre.fr; *catherine.taillier@univ-lehavre.fr

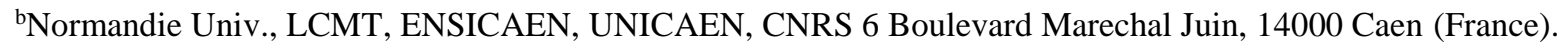

\begin{abstract}
We report the preparation of phosphiranium salts by quaternarization of phosphiranes, a class of sensitive, highly strained and poorly nucleophilic cyclic phosphines. High yielding introduction of a varied set of alkyl groups including methylene ester arms was accomplished under mild conditions. A Cu-catalyzed electrophilic arylation of phosphiranes using diaryl iodonium reagents was also achieved to yield unprecedented $\mathrm{P}, \mathrm{P}$ diaryl phosphiranium salts with good efficiency.
\end{abstract}

Key words: Alkylation, Arylation, Phosphirane, Phosphiranium salt, Alkylating agent, Diaryliodonium salt

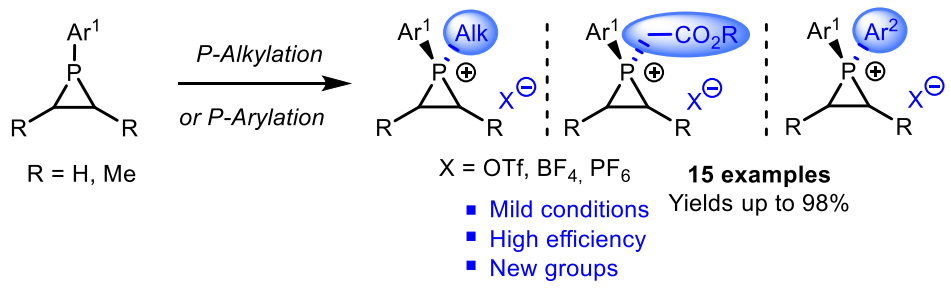

Nowadays, quaternary phosphonium salts (QPS) represent an important class of organophosphorus compounds which have found a broad spectrum of applications ranging from catalysis, organic synthesis to biological and medical applications. ${ }^{1}$ It is therefore not surprising that the access to a large panel of QPS has been widely documented. Until recently, most of the QPS syntheses exploited the nucleophilic properties of phosphorus non-bonded lone pair of electrons to form new bonds with a variety of electrophilic species. ${ }^{2}$ In particular, the direct introduction of alkyl groups on tertiary phosphines using alkyl halides $(\mathrm{Cl}, \mathrm{Br}, \mathrm{I})$ or related sulfonates (Ms, Ts, Tf) as electrophilic partners has been extensively exploited over the years.

Compared to regular phosphines, the reactivity of phosphiranes, which are rather uncommon sub-types of cyclic phosphines, was only scarcely studied (Scheme 1). These three-membered phosphorus heterocyclic systems have been viewed for long as elusive species being largely neglected by the synthetic community. One main reason is that phosphiranes were generally appreciated as highly strained species, moderately stable thermodynamically and, in many instances, subject to ring-fragmentations or rearrangements. ${ }^{3}$

Moreover, theoretical calculations also revealed that strain of the small P-heterocycles would cause partial delocalization of the phosphorus lone pair over the cycle, resulting in a decrease of nucleophilicity in comparison to tertiary phosphines. ${ }^{4}$ In light of these structural characteristics and the resultant reactivity uncertainties, the chemistry of phosphiranes, and in particular quaternarization has been barely approached. To our knowledge, only a handful of such quaternarizations has been reported, all of which being performed using the highly electrophilic alkylating agent methyl trifluoromethanesulfonate. ${ }^{5}$ Hence, the assessment that phosphiranes can 
undergo quaternarization with reliability and wide scope is still awaited. We have recently endeavored to tackle this problem and now report our preliminary results showcasing that phosphiranes are promising platform for easy synthesis of quaternary phosphiranium salts (QPrS) by alkylative and arylative functionalization. In particular, an assortment of new derivatives, including P-alkyl, Pmethylene ester and $\mathrm{P}$-aryl units, with appealing and untapped potential reactivity in organic synthesis has been prepared.

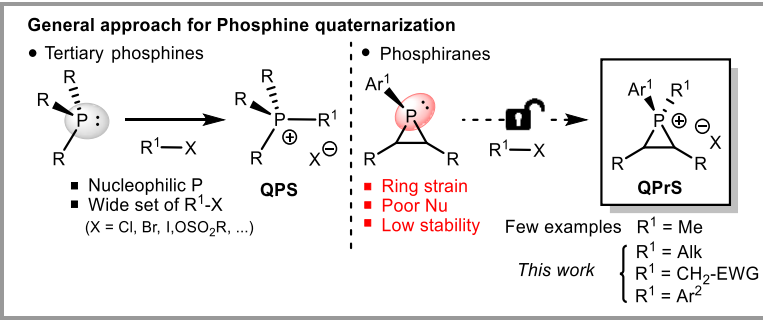

Scheme 1. General statement for tertiary phosphines (left) and phosphiranes (right)quaternarization;

Since we observed at the early stage of this study that introduction of large substituents on phosphorus significantly mitigated instability issues, we first selected as a model substrate phosphirane 1a incorporating a mesityl (Mes=2,4,6trimethylphenyl) substituent on $\mathrm{P}$, for imparting the ideal balance of thermal stability / resistance to airoxidation / reactivity. 1a was prepared from its parent primary phosphine $\mathrm{MesPH}_{2}$ using a straightforward one-step reaction procedure. ${ }^{6}$

A preliminary study first focused on the screening of classical methylating agents and reaction conditions for P-methylation of $\mathbf{1 a}{ }^{7}$ Of the set of reagents tested, only the highly electrophilic methyl trifluoromethanesulfonate MeOTf appeared sufficiently reactive to enable alkylation and form the desired phosphiranium salt $\mathbf{2 a}$ in almost quantitative isolated yield (Cond. A, Scheme 2). ${ }^{8}$ This stands in full agreement both with literature precedents and the expected weak nucleophilicity of 1a resulting from the sterics and the ring strain/electronics relationship discussed above.

Like any strained three-membered ring-systems, phosphiranium triflate $\mathbf{2 a}$ is characterized by extreme high field ${ }^{1} \mathrm{H},{ }^{13} \mathrm{C}$ and ${ }^{31} \mathrm{P}$ chemical shifts as well as large ${ }^{1} \boldsymbol{J}_{(\mathrm{C}-\mathrm{P})}$ coupling constants. ${ }^{9}{ }^{910}$ It should also be noticed that, in the absence of air and water, the phosphiranium 2a appeared completely stable over several months when stored at $-20^{\circ} \mathrm{C}$. Modulation of aryl substituents on phosphorus was next evaluated. Preparation of the corresponding Pmethyl,P-supermesityl phosphiranium $\mathbf{2 b}$ and its $\mathrm{P}$ phenyl analogue 2c was again performed using MeOTf (1 equivalent) at room temperature in dichloromethane. Both reactions were rapid and clean, requiring only $2 \mathrm{~h}$ of stirring at $\mathrm{rt}$ to reach completion and give the desired compounds in high yields (Cond. A, $95 \%$ and $80 \%$, respectively from phosphiranes $\mathbf{1 b}$ and 1c). The high yielding synthesis of phosphiranium 1c adorned with a simple phenyl deserves particular mention, given the relatively modest shielding embedding this substituent.

The quaternarization of C-substituted phosphiranes was next considered. Phosphiranes 1d and 1e respectively incorporating one or two methyl groups on the ring were then reacted with methyl trifluoromethanesulfonate (Cond. A). Fast reactions were again observed leading to full conversion of both phosphiranes $\mathbf{1 d}$ and $\mathbf{1 e}$ within $1 \mathrm{~h}$ to form the corresponding salts $\mathbf{2 d}$ and 2 e. $^{11}$ On one hand, the mono-substituted phosphiranium 2d could be isolated in $98 \%$ yield as a mixture of diastereoisomers $(\mathrm{dr}$ anti/syn $=77 / 23) .{ }^{12} \mathrm{As}$ observed in the parent phosphirane series, the Csubstituted phosphiranium salt $2 \mathbf{d}$ appeared to be much less stable than its unsubstituted analog $\mathbf{2 a}$, and partial degradation occurred after only a few hours at rt. These instability issues increased even further with additional substitution as shown by the significant proportion of degradation products formed when attempting to isolate the di-substituted phosphiranium salt $2 \mathrm{e}$ from the reaction mixture. ${ }^{13}$

To verify whether the nature of the counter-anion could also be modified, P-methylation of $\mathbf{1 a}$ was next tested using the Meerwein reagent $(\mathrm{Me})_{3} \mathrm{O}^{+} \mathrm{BF}_{4}^{-}$ . The latter was found equally effective as methyl triflate to form the corresponding phosphiranium tetrafluoroborate salt $2 \mathbf{f}$ in high yield within $2 \mathrm{~h}$ $\left(96 \%\right.$, Cond. B) ${ }^{8}$

Rewardingly, it was also shown that the quaternarization step could expand beyond methylation. Indeed, we were pleased to succeed in the P-allylation and P-benzylation of the phosphirane 1a to afford the phosphiranium triflates 3a and 3b, which were isolated in good yields when a sequential one-pot triflation/alkylation protocol was applied from allyl and benzyl alcohols, respectively (Cond. C ). ${ }^{14,15}$

Formation of the P-ethyl phosphiranium salt $\mathbf{3 c}$ was also attempted from phosphirane 1a using the commercially available ethyl triflate. ${ }^{16}$ In this case, a prolonged reaction time of $16 \mathrm{~h}$ and heating at $50{ }^{\circ} \mathrm{C}$ (Cond. C) were found critical to reach completion and, although the desired QPrS 3c could be formed as the major product, extensive decomposition was also observed preventing its isolation in pure form. ${ }^{17}$

To broaden diversity and open new perspectives for further functionalization, introduction of methylene ester $\left(-\mathrm{CH}_{2} \mathrm{CO}_{2} \mathrm{R}\right)$ groups on phosphirane 1a was next considered. Since we expected an increased electrophilicity of the $-\mathrm{CH}_{2}$ group adjacent to the 
proximal ester with respect to the methyl, allyl and benzyl halides, we first tested use of the commercially available bromo- and iodoacetate derivatives. Apart from avoiding the tedious glycolic esters-derived triflate route while providing a simplified protocol, these experiments were also intended to bring valuable information refining our knowledge of phosphiranes general reactivity.

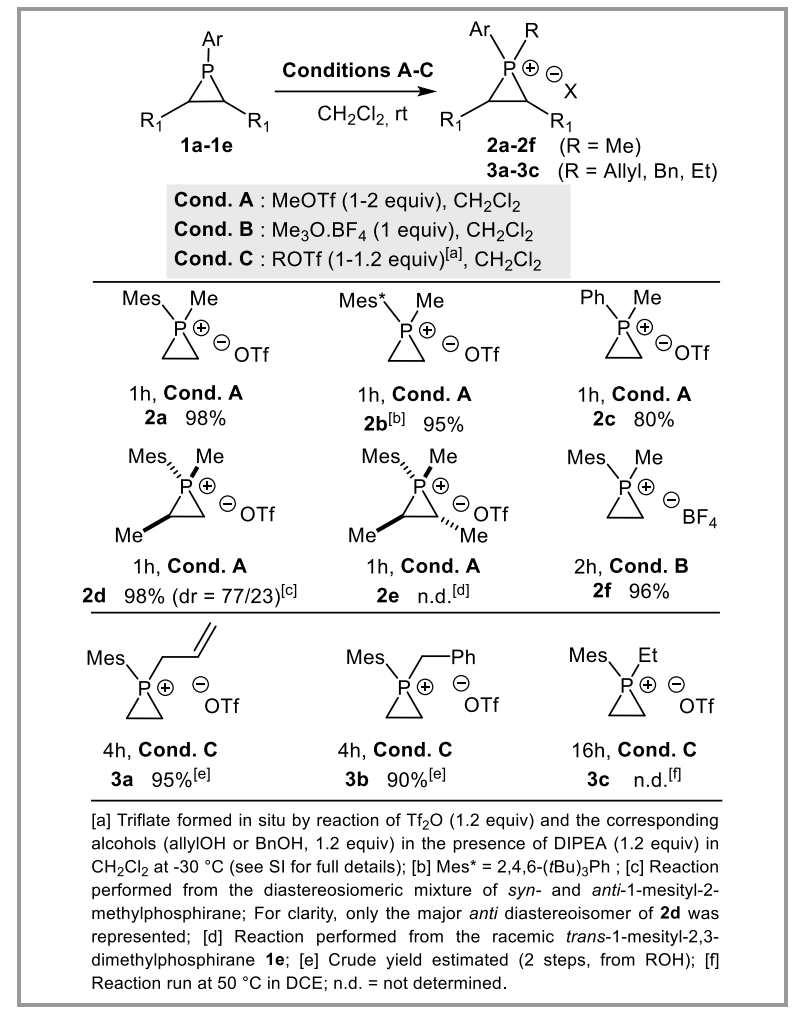

Scheme 2. Preparation of P-alkyl phosphiranium salts 2-3

In line with earlier observations in methyl, allyl and benzyl series, a lack of reactivity was, unfortunately, observed with only partial conversion of 1a and degradation observed after prolonged reaction times. So we finally had to resort to synthesizing the corresponding triflate reagents from the parent hydroxy esters. The triflation step was, somehow surprisingly, a clean process which enabled easy and high yielding $(70-82 \%)$ isolation of the desired triflates 4a-4d. Their reaction with 1a all proceeded smoothly to give the expected methylene ester phosphiranium triflates 5a-5d in high yields (80$95 \%$ ) irrespective of the ester group (Scheme 3). ${ }^{18,19}$

In all cases, slow reaction rates were observed and the reactions required an extended reaction time of $24 \mathrm{~h}$ (versus $2 \mathrm{~h}$ for methylation) at room temperature to reach completion. Heating and solvent change were also tested without any improvement. As a whole, triflyloxy acetates $\mathbf{4 a - 4 d}$ turned out to be much more reactive than the corresponding halides, but clearly less than methyl triflate, thereby confirming the weak nucleophilicity of phosphiranes while demonstrating the dominant influence of sterics on reactivity. Disappointingly and for some unclear reasons, attempts to switch the ester function by a trifluoromethyl group completely suppressed the alkylation, and no trace of the corresponding quaternary phosphiranium salt $\mathbf{5 e}$ could be detected when mixing 1a with the trifluoroethyl triflate $\mathbf{4 e}$.

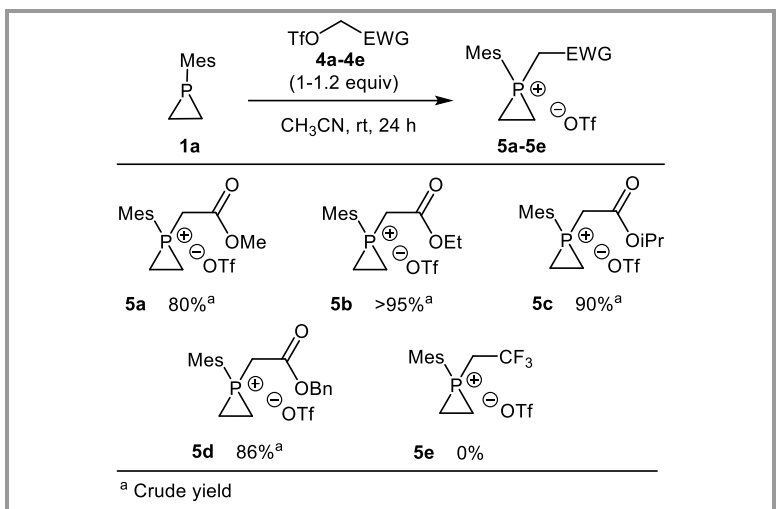

Scheme 3. Preparation of P-methylene ester phosphiranium triflates $\mathbf{5 a - 5 e}$

To further expand our phosphiranium salts portfolio, we next focused on the introduction of aryl groups on phosphirane 1a. We postulated that hypervalent iodine derivatives should be suitable reagents for diarylphosphiranium salt synthesis through electrophilic arylation of phosphirane substrates, ${ }^{20,21}$ thus opening new perspectives in phosphirane functionalization. We were delighted to be able to demonstrate that this was indeed the case.

Table 2 shows selected results of our preliminary exploration of a $\mathrm{Cu} / \mathrm{CuCl}$-catalyzed arylative quaternarization reaction of $\mathbf{1 a}$ with diaryliodonium triflates 6a-6c. ${ }^{20 \mathrm{~d}, 22}$ Reaction of 1a with $\mathbf{6 a}$ was initially conducted in 1,1,2,2-tetrachloroethane at $140{ }^{\circ} \mathrm{C}$. Under these relatively drastic reaction conditions the diaryl phosphiranium salt 7a was isolated in only $12 \%$ yield from the reaction mixture, in spite of complete conversion (entry 1). To limit decomposition, we next performed a series of reactions at lower temperatures and observed progressive yields enhancement following gradual decrease of the temperature $\left(48 \%\right.$ at $80{ }^{\circ} \mathrm{C} v s 81 \%$ at $50{ }^{\circ} \mathrm{C}$, entries 2-3). A complete absence of reactivity was however observed at room temperature (entry 4). It is worth mentioning that P,Pdiarylphosphiranium salt $\mathbf{7 a}$ proved less stable than its P-Me,P-aryl analog 2a, with faster decomposition occurring in solution even at room temperature. 7a was however found stable enough to be isolated by flash column chromatography on silica gel and could be stored neat for weeks at $-20^{\circ} \mathrm{C}$, in the absence of 
air and water. Preparation of the hexafluorophosphate salt analog $\mathbf{7 b}$ was run in the same conditions using diphenyliodonium salt $\mathbf{6 b}$. In stark contrast with the triflate case, temperature influenced the reaction outcome only marginally (54\% isolated yield at $80{ }^{\circ} \mathrm{C} v s 58 \%$ at $50{ }^{\circ} \mathrm{C}$, entries 5 and 6 respectively), thereby suggesting a greater instability of P,P-diaryl QPrs paired with a hexafluorophosphate anion.

Last, introduction of the electron rich and bulky $p$ tert-butylphenyl group on $\mathbf{1 a}$ was attempted. Although the starting phosphirane 1a was rapidly consumed either at $80{ }^{\circ} \mathrm{C}$ or $50^{\circ} \mathrm{C}$, the phosphiranium hexafluorophosphate salt 7c was isolated in only $14 \%$ and $27 \%$ yields respectively (entries 7 and 8). At this stage, it is not clear whether these low yields reflect an exacerbated instability of QPrS 7c under the reaction conditions or are the results of an unfavorable aryl transfer.

In conclusion, we have described the preparation of unprecedented quaternary phosphiranium salts, an intriguing and barely explored class of quaternary phosphonium salts.

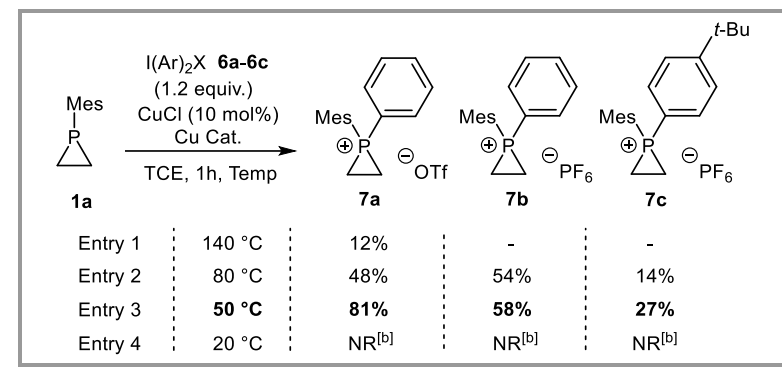

Scheme 4. Arylation of phosphirane 1a with diaryliodonium reagents: Reaction conditions optimization $^{[\mathrm{a}]}$ ([a] Isolated yield; ${ }^{[\mathrm{b}]} \mathrm{NR}=$ no reaction)

To this end, the singular reactivity of their phosphirane precursors, which are highly strained and poorly nucleophilic cyclic phosphines, was studied with regard to quaternarization. Introduction of a varied set of alkyl substituents, ranging from methyl to methylene ester groups, could be accomplished in high yields when using the triflate reagents as the alkylating agents. For triflates which are not commercially available and highly sensitive, a straightforward and efficient one-pot triflation/alkylation procedure was developed. We have also demonstrated that use of hypervalent iodine reagents in a $\mathrm{Cu}$-catalyzed electrophilic arylation of phosphirane substrates could offer a facile access to bis-arylated compounds, thus broadening our library of phosphiranium salts. This work allowed access to known and new structures with fascinating yet untapped synthetic potential for new phosphorus chemistry. Studies on those aspects are currently ongoing in our laboratory and will be reported in due course.

\section{Acknowledgment}

We gratefully acknowledge the region HauteNormandie, the réseau CRUNCH for grants to JG and CB. JG also thanks the University Le Havre Normandie for financial support.

\section{References and Notes}

(1) Berchel, M.; Jaffrès, P.-A. In Organophosphorus Chemistry: From Molecules to Applications; 1st ed.; Iaroshenko, V., Ed.; Wiley- VCH, 2019, pp. 59111 and references cited therein..

(2) (a) Virieux, D.; Volle, J.-N.; Pirat, J.-L. In Science of Synthesis, Vol. 42; Mathey, F., Trost, B. M. Ed.; Thieme: Stuttgart, 2009, pp. 503-594; (b) Tebby, J. C.; Allen, D. W. In Science of Synthesis, Vol. 31; Ramsden, C. A. Ed.; Thieme: Stuttgart, 2007, pp. 2083-2104. (c) For the first example of QPS synthesis utilizing phosphine oxides as electrophilic partners and Grignard reagents as nucleophiles, see: Vetter, A. C.; Nikitin, K.; Gilheany, D. G. Chem. Commun. 2018, 54, 5843.

(3) (a) Mathey, F. Chem. Rev. 1990, 90, 997; (b) Quin, L. D. in A Guide to Organophosphorus Chemistry; Quin, L. D. Ed.; John Wiley Sons, New York, 2000, 234; (c) Mathey, F.; Regitz, M. in PhosphorusCarbon Heterocyclic Chemistry: The Rise of a New Domain; Mathey, F. Ed.; Elsevier Science, Amsterdam, 2001, 17.

(4) Henderson, W. A.; Buckler, S. A. J. Am. Chem. Soc. 1960, 82, 5794.

(5) (a) Hockless, D. C. R.; McDonald, M. A.; Pabel, M.; Wild, S. B. J. Chem. Soc., Chem. Commun. 1995, 257; (b) Hockless, D. C. R.; McDonald, M. A.; Pabel, M.; Wild, S. B. J. Organomet. Chem. 1997, 529, 189; (c) For another recent example of isolated QPrS, see: Ficks, A.; Martinez-Botella, I.; Stewart, B.; Harrington, R. W.; Clegg, W.L.; Higham, J. Chem. Commun. 2011, 47, 8274.

(6) For the synthesis of phosphirane substrates, see: (a) Mézailles, N.; Fanwick, P. E.; Kubiak, C. P. Organometallics 1997, 16, 1526; (b) Yang, F.; Fanwick, P. E.; Kubiak, C. P. Organometallics 1999, 18, 4222.

(7) Partial conversions of phosphirane 1a to the corresponding $P$-methyl phosphiranium salts were observed after prolonged reaction times using other methylating agents by ${ }^{31} \mathrm{P}-\mathrm{NMR}$ monitoring. Attempts to complete the methylation reactions all failed to give the products in satisfactory yields. Prolonged reaction times and heating were rather found to favor degradation of both substrate 1a and quaternarization products. Results not shown.

(8) General procedure for the preparation of P-Me phosphiranium salts 2 (conditions $A$ or $B$ ): To a solution of phosphirane $\mathbf{1}$ (1.0 equiv) in $\mathrm{CH}_{2} \mathrm{Cl}_{2}(0.5$ $\mathrm{M})$ was added methyl trifluoromethanesulfonate or trimethyloxonium tetrafluoroborate (1.0-2.0 equiv) dropwise at room temperature. The mixture was then stirred at room temperature and conversion of the starting material was monitored by ${ }^{31} \mathrm{P}$ NMR (approximatively $2 \mathrm{~h}$ ). The reaction mixture was then concentrated under reduced pressure to give the title compounds 2. 1-mesityl-1-methylphosphiran1-ium trifluoromethane-sulfonate (2a) Prepared 
from 1-mesitylphosphirane 1a $(0.84 \mathrm{mmol})$ using the general procedure with methyl trifluoromethanesulfonate (2.0 equiv). Reaction time: $2 \mathrm{~h}$. The title compound $\mathbf{2 a}$ was isolated as a white solid (290 mg, 99\% yield). $\boldsymbol{R} \boldsymbol{f}=0.40$ (DCM/ EtOAc: 60/40); $\mathbf{m p ~} 58-60{ }^{\circ} \mathrm{C}$; IR (neat) $v$ 2941, 1604, 1250, 1031, $940 \mathrm{~cm}^{-1}$; ${ }^{1} \mathbf{H}$ NMR $(300 \mathrm{MHz}$, $\left.\mathrm{CDCl}_{3}, 20^{\circ} \mathrm{C}\right) \delta 6.99\left(\mathrm{~d},{ }^{4} J_{H-P}=6.0 \mathrm{~Hz}, 2 \mathrm{H}\right), 2.74-$ $2.60(\mathrm{~m}, 2 \mathrm{H}), 2.57\left(\mathrm{~d},{ }^{4} J_{H-P}=1.6 \mathrm{~Hz}, 6 \mathrm{H}\right), 2.26(\mathrm{~s}$, $3 \mathrm{H}), 2.20\left(\mathrm{~d},{ }^{2} J_{H-P}=17.8 \mathrm{~Hz}, 3 \mathrm{H}\right), 2.15-2.03(\mathrm{~m}$, $2 \mathrm{H}) ;{ }^{13} \mathrm{C} \mathrm{NMR}\left(75 \mathrm{MHz}, \mathrm{CDCl}_{3}, 20^{\circ} \mathrm{C}\right) \delta 146.9(\mathrm{~d}$, $\left.{ }^{4} J_{C-P}=3.0 \mathrm{~Hz}, \mathrm{Cq}\right), 144.5\left(\mathrm{~d},{ }^{3} J_{C-P}=11.0 \mathrm{~Hz}, 2 \mathrm{CH}\right)$, $130.0\left(\mathrm{~d},{ }^{2} J_{C-P}=13.2 \mathrm{~Hz}, 2 \mathrm{Cq}\right), 120.3\left(\mathrm{q},{ }^{1} J_{C-F}=\right.$ $320.2 \mathrm{~Hz}, \mathrm{Cq}), 110.7$ (d, $\left.{ }^{1} J_{C-P}=93.8 \mathrm{~Hz}, \mathrm{Cq}\right), 22.0$ $\left(\mathrm{d},{ }^{3} J_{C-P}=9.1 \mathrm{~Hz}, 2 \mathrm{CH}_{3}\right), 21.3\left(\mathrm{~d},{ }^{5} J_{C-P}=1.7 \mathrm{~Hz}\right.$, $\left.\mathrm{CH}_{3}\right), 9.3\left(\mathrm{~d},{ }^{1} J_{C-P}=4.4 \mathrm{~Hz}, 2 \mathrm{CH}_{2}-\mathrm{P}\right), 5.4\left(\mathrm{~d},{ }^{1} J_{C-P}\right.$ $\left.=50.1 \mathrm{~Hz}, \underline{\mathrm{CH}_{3}}-\mathrm{P}\right) ;{ }^{31} \mathbf{P}$ NMR (121 $\mathbf{~ M H z}, \mathbf{C D C l}_{3}$, $\left.\mathbf{2 0}^{\circ} \mathbf{C}\right) \delta-116.1 ;{ }^{19} \mathrm{~F}$ NMR $\left(282 \mathrm{MHz}, \mathrm{CDCl}_{3}, 20^{\circ} \mathrm{C}\right)$ $\delta$-78.4; HRMS (ESI) $\mathrm{m} / \mathrm{z}$ calculated for $\mathrm{C}_{12} \mathrm{H}_{18} \mathrm{P}$ $[\mathrm{M}]^{+}:$193.1146, found 193.1144

(9) The ${ }^{31} \mathrm{P}$ NMR spectrum shows a single peak at $116.4 \mathrm{ppm}$ for $\mathbf{2 a}$, while the methyl group on $\mathrm{P}$ appears as a doublet at $2.20 \mathrm{ppm}\left({ }^{2} J_{\mathrm{P}-\mathrm{H}}=17.8 \mathrm{~Hz}\right)$ in the ${ }^{1} \mathrm{H}$ NMR spectrum. In comparison, acyclic phosphonium analog of 2a gives a signal at +21.2 ppm in the ${ }^{31} \mathrm{P}$ NMR spectrum, see : Sattler, A.; Parkin, G. Chem. Commun. 2011, 47, 12828

(10) Similarly, phosphiranes give the most upfield ${ }^{31} \mathrm{P}$ NMR signals known for tertiary phosphines. As a representative example, our model phosphirane 1a gives a signal at $-240.4 \mathrm{ppm}$ in the ${ }^{31} \mathrm{P}$ NMR spectrum.

(11) (a) The stereochemistry anti and syn refers to the relative position of the substituent on the ring carbon to the mesityl substituant at phosphorus; The reaction was performed from a diastereosiomeric mixture of syn- and anti-1-mesityl-2methylphosphirane 1d; (b) The reaction was performed from the racemic trans-1-mesityl-2,3dimethylphosphirane 1e.

(12) (a) Stereochemistry of the products $\mathbf{2 d}$ and $\mathbf{2 e}$ are proposed by analogy and in accordance with Gaspar and co-workers' work who described the stereoselective synthesis of the parent phosphiranes 1d and 1e, see: Li, X.; Robinson, K. D.; Gaspar, P. P. J. Org. Chem. 1996, 61, 7702; (b) It is worth noting that due to instability issues, which differ from one diastereomer to another in both the phosphirane and the phosphiranium series, significant variations in the dr values of the isolated products may be observed.

(13) It should be noted that due to their increased instability: (a) HRMS and IR data are missing from the characterization of phosphiranium 2d; (b) neither determination of a reliable chemical yield nor full characterization of the quaternarization product $2 \mathrm{e}$ could be done.

(14) Isolation of both allyl and benzyl triflate could not be realized. Therefore, in situ formation of the triflate reagents and direct addition of the reaction mixture onto a dichloromethane solution of phosphirane 1a at $-30{ }^{\circ} \mathrm{C}$ was realized. For a similar procedure involving formation and direct use of allyl triflate, see: Corey, E.J.; Helal, C. J. Tetrahedron Lett. 1996, 37, 5675

(15) General procedure for the preparation of P-alkyl phosphiranium triflate 3 (conditions C): To a solution of diisopropylethylamine (1.2 equiv) and the corresponding alkyl alcohol (1.2 equiv) in dry $\mathrm{CH}_{2} \mathrm{Cl}_{2}(0.6 \mathrm{M})$ at $-30{ }^{\circ} \mathrm{C}$ was added dropwise trifluoromethanesulfonic anhydride (1.2 equiv) under argon atmosphere. The reaction mixture was successively stirred $10 \mathrm{~min}$ at $-30{ }^{\circ} \mathrm{C}$, warmed to 0 ${ }^{\circ} \mathrm{C}$ and stirred for $10 \mathrm{~min}$. The reaction mixture was again cooled to $-30{ }^{\circ} \mathrm{C}$. Then, dry $\mathrm{Et}_{2} \mathrm{O}$ was added to precipitate the ammonium salts. After decantation, the supernatant solution was added dropwise to a solution of phosphirane 1 ( 1 equiv) in dry $\mathrm{CH}_{2} \mathrm{Cl}_{2}(1$ $\mathrm{M})$ at $-50{ }^{\circ} \mathrm{C}$. The reaction mixture was then allowed to warm to room temperature over a period of $4 \mathrm{~h}$ and stirring was pursued at room temperature. Conversion of the starting material was monitored by ${ }^{31} \mathrm{P}$ NMR. Evaporation of the solvent under reduced pressure then afforded the title product 3. 1allyl-1-mesitylphosphiranium trifluoromethanesulfonate (3a) Prepared from 1-mesitylphosphirane $1 \mathrm{a}(0.84 \mathrm{mmol})$ using the general procedure with allyl alcohol (1.2 equiv). Reaction time: $4 \mathrm{~h}$. The title compound 3a was isolated as a thick colorless oil (350 mg, 95\% crude yield). $\boldsymbol{R} \boldsymbol{f}=0.15$ (AcOEt); IR (neat) $v$ 2944, 1605, 1250, 1153, 1025, $940 \mathrm{~cm}^{-}$ ${ }^{1}$; ${ }^{1} \mathbf{H}$ NMR $\left(300 \mathrm{MHz}, \mathrm{CDCl}_{3}, 20^{\circ} \mathrm{C}\right) \delta 7.03\left(\mathrm{~d},{ }^{4} J_{H-}\right.$ $P=5.7 \mathrm{~Hz}, 2 \mathrm{H}), 5.70(\mathrm{~m}, 1 \mathrm{H}), 5.55-5.39(\mathrm{~m}, 2 \mathrm{H})$, $3.41\left(\mathrm{dd},{ }^{2} J_{H-P}=18.7 \mathrm{~Hz}\right.$ and $\left.{ }^{3} J_{H-H}=7.6 \mathrm{~Hz}, 2 \mathrm{H}\right)$, 2.78-2.68 (m, 2H), 2.58 (bs, 6H), 2.31 (s, 3H), 2.20$2.10(\mathrm{~m}, 2 \mathrm{H}){ }^{13} \mathbf{C}$ NMR $\left(75 \mathrm{MHz}, \mathrm{CDCl}_{3}, 20^{\circ} \mathrm{C}\right) \delta$ $147.3\left(\mathrm{~d},{ }^{4} J_{C-P}=3.2 \mathrm{~Hz}, \mathrm{Cq}\right), 145.2\left(\mathrm{~d},{ }^{3} J_{C-P}=10.8\right.$ $\mathrm{Hz}, 2 \mathrm{CH}), 130.2\left(\mathrm{~d},{ }^{2} J_{C-P}=13.3 \mathrm{~Hz}, 2 \mathrm{Cq}\right), 125.3$ $\left(\mathrm{d},{ }^{3} J_{C-P}=16.2 \mathrm{~Hz}, \mathrm{CH}_{2}\right), 123.5\left(\mathrm{~d},{ }^{2} J_{C-P}=14.0 \mathrm{~Hz}\right.$, $\mathrm{CH}), 120.3\left(\mathrm{q},{ }^{1} J_{C-F}=319.6 \mathrm{~Hz}, \mathrm{CF}_{3}\right), 109.3\left(\mathrm{~d},{ }^{1} J_{C}\right.$ $P=86.1 \mathrm{~Hz}, \mathrm{Cq}), 25.8\left(\mathrm{~d},{ }^{1} J_{C-P}=42.6 \mathrm{~Hz}, \underline{\mathrm{CH}_{2}}-\mathrm{P}\right)$, $22.5\left(\mathrm{~d},{ }^{3} J_{C-P}=7.9 \mathrm{~Hz}, 2 \mathrm{CH}_{3}\right), 21.5\left(\mathrm{~d},{ }^{5} J_{C-P}=1.2\right.$ $\left.\mathrm{Hz}, \mathrm{CH}_{3}\right), 9.0$ (m, $\left.2 \underline{\mathrm{CH}}_{2}-\mathrm{P}\right) ;{ }^{31} \mathbf{P}$ NMR (121 MHz, $\left.\mathrm{CDCl}_{3}, 20^{\circ} \mathrm{C}\right) \delta-114.1 ;{ }^{19} \mathbf{F}$ NMR $(282 \mathrm{MHz}$, $\mathrm{CDCl}_{3}, 20^{\circ} \mathrm{C}$ ) $\delta-78.5$; HRMS (ESI) $\mathrm{m} / \mathrm{z}$ calculated for $\mathrm{C}_{14} \mathrm{H}_{20} \mathrm{P}[\mathrm{M}]^{+}:$219.1303, found: 219.1298

(16) Crude yield estimated from ${ }^{1} \mathrm{H}$ NMR analysis of the crude mixture

(17) Formation of $P$-ethyl phosphiranium triflate $\mathbf{3 c}$ as a major product was observed by monitoring progress of the quaternarization reaction starting from phosphirane 1a by ${ }^{1} \mathrm{H}$ and ${ }^{31} \mathrm{P}$ NMR. The ${ }^{31} \mathrm{P}$ NMR spectrum shows a single peak at $-109.6 \mathrm{ppm}$ for $\mathbf{3 c}$, while the ethyl group on $\mathrm{P}$ appears as a dt at 1.42 $\operatorname{ppm}\left(3 \mathrm{H},{ }^{3} J_{\mathrm{P}-\mathrm{H}}=27.0 \mathrm{~Hz}\right.$ and $\left.{ }^{3} J_{\mathrm{H}-\mathrm{H}}=7.6 \mathrm{~Hz}\right)$ and a multiplet at $2.50-2.25 \mathrm{ppm}(2 \mathrm{H})$ in the ${ }^{1} \mathrm{H}$ NMR spectrum.

(18) General procedure for the preparation of $\mathbf{P}$ methylene ester phosphiranium triflates 5: a) Triflate reagents formation: To a solution of the corresponding glycolic ester (1 equiv) and pyridine (1.3 equiv) in $\mathrm{CH}_{2} \mathrm{Cl}_{2}(0.25 \mathrm{M})$ at $-10^{\circ} \mathrm{C}$, was added triflic anhydride (1.15 equiv) dropwise, under argon atmosphere. Reaction was stirred $1 \mathrm{~h}$ at $-10^{\circ} \mathrm{C}$ and $3.5 \mathrm{~h}$ at room temperature. Degazed water $(0.2 \mathrm{M})$ was next added to the reaction mixture. After decantation, the aqueous layer was extracted with $\mathrm{CH}_{2} \mathrm{Cl}_{2}$ (3 x $5 \mathrm{~mL} / \mathrm{mmol}$ ). The combined organic layers were then combined, dried over $\mathrm{MgSO}_{4}$, filtered and concentrated under vacuum to give the corresponding triflate reagents 4. b) Alkylation of phosphirane 1: To a solution of phosphirane (1 equiv) in $\mathrm{MeCN}(0.2 \mathrm{M})$ was added the corresponding triflate reagent 4 (1 equiv). The reaction mixture was then stirred at room temperature under argon atmosphere until complete 
conversion of phosphirane 1 ( ${ }^{31} \mathrm{P}$ NMR monitoring, approximatively 24 hours). The solvent was then removed under vacuum to give the crude methylene ester phosphiranium salts 5. 1-mesityl-1-(2-ethoxy2-oxoethyl)phosphiran-1-ium trifluoromethanesulfonate (5b) Prepared from 1-mesitylphosphirane 1a $(0.40 \mathrm{mmol})$ using the general procedure with the triflate reagent derived from ethyl glycolate (1.0 equiv). Reaction time: $24 \mathrm{~h}$. The title compound $\mathbf{5 b}$ was isolated as a thick colorless oil (394 mg, 95\% crude yield). $\boldsymbol{R} \boldsymbol{f}=0.23$ (50/50 DCM/Acetone); IR (neat) $v$ 2985, 1724, 1606, 1243, 1223, 1156, 1027 $\mathrm{cm}^{-1} ;{ }^{1} \mathbf{H}$ NMR $\left(300 \mathrm{MHz}, \mathrm{CDCl}_{3}, 20^{\circ} \mathrm{C}\right) \delta 7.09(\mathrm{~d}$, $\left.{ }^{4} J_{P-H}=6.2 \mathrm{~Hz}, 2 \mathrm{H}\right), 4.19\left(\mathrm{q},{ }^{3} J_{H-H}=7.2 \mathrm{~Hz}, 2 \mathrm{H}\right)$, $4.03\left(\mathrm{~d},{ }^{2} J_{P-H}=16.8 \mathrm{~Hz}, 2 \mathrm{H}\right), 3.17-3.07(\mathrm{~m}, 2 \mathrm{H})$, $2.71(\mathrm{~s}, 6 \mathrm{H}), 2.37$ (s, 3H), 2.28-2.18 (m, $2 \mathrm{H}), 1.24$ $\left(\mathrm{t},{ }^{3} \mathrm{~J}_{\mathrm{H}-\mathrm{H}}=7.2 \mathrm{~Hz}, 3 \mathrm{H}\right) ;{ }^{13} \mathbf{C} \mathbf{~ N M R}\left(75 \mathrm{MHz}, \mathrm{CDCl}_{3}\right.$, $\left.20^{\circ} \mathrm{C}\right) \delta 164.6\left(\mathrm{~d},{ }^{2} J_{P-C}=5.1 \mathrm{~Hz}, \mathrm{C}=\mathrm{O}\right), 147.7(\mathrm{~d}$, $\left.{ }^{4} J_{P-C}=3.2 \mathrm{~Hz}, \mathrm{Cq}\right), 145.7\left(\mathrm{~d},{ }^{3} J_{P-C}=11.4 \mathrm{~Hz}, 2 \mathrm{CH}\right)$, $130.5\left(\mathrm{~d},{ }^{2} J_{P-C}=14.0 \mathrm{~Hz}, 2 \mathrm{Cq}\right), 120.4\left(\mathrm{q},{ }^{1} J_{F-C}=\right.$ $\left.319.4, \mathrm{CF}_{3}\right), 109.1\left(\mathrm{~d},{ }^{1} J_{P-C}=93.0 \mathrm{~Hz}, \mathrm{Cq}\right), 63.5$ $\left(\mathrm{CH}_{2}\right), 30.0\left(\mathrm{~d},{ }^{1} J_{P-C}=56.2 \mathrm{~Hz}, \underline{\mathrm{CH}_{2}}-\mathrm{P}\right), 22.4\left(\mathrm{~d},{ }^{3} J_{P-}\right.$ $\left.C=8.5 \mathrm{~Hz}, 2 \mathrm{CH}_{3}\right), 21.7\left(\mathrm{~d},{ }^{5} \overline{J_{P-C}}=1.6 \mathrm{~Hz}, \mathrm{CH}_{3}\right)$, $13.8\left(\mathrm{CH}_{3}\right), 10.3\left(\mathrm{~d},{ }^{1}{ } P_{-C}=2.7 \mathrm{~Hz}, 2 \mathrm{CH}_{2}-\mathrm{P}\right) ;{ }^{31} \mathbf{P}$ NMR $\left(121 \mathrm{MHz}, \mathrm{CDCl}_{3}, 20^{\circ} \mathrm{C}\right) \delta-118.6 ;{ }^{19} \mathbf{F ~ N M R}$ $\left(282 \mathrm{MHz}, \mathrm{CDCl}_{3}, 20^{\circ} \mathrm{C}\right) \delta$-78.5; HRMS (ESI) $\mathrm{m} / \mathrm{z}$ calculated for $\mathrm{C}_{15} \mathrm{H}_{22} \mathrm{O}_{2} \mathrm{P} \quad[\mathrm{M}]^{+}: \quad 265.1357$, found 265.1360 .

(19) Crude yield are given since purification attempts only led to the decomposition of the products.

(20) For examples of metal-catalyzed arylation of tertiary phosphines, see: (a) Ziegler, Jr., C. B.; Heck, R. F. J. Org. Chem. 1978, 43, 2941; (b) Marcoux, D.; Charette, A. B. J. Org. Chem. 2008, 73, 590; (c) Marcoux, D.; Charette, A. B. Adv. Synth. Catal. 2008, 350, 2967; (d) Hanamoto, T.; Kiguchi, Y.; Shindo, K.; Matsuoka, M.; Kondo, M. Chem. Commun. 1999, 151; (e) For a photo-redox-reaction mediated by a Ru-based photosensitizer, see: Fearnley, A. F.; An, J.; Lindovska, P.; Denton, R. M. Chem. Commun. 2016, 52, 4987.

(21) For examples of metal-free arylation methods, see: (a) Wittig, G.; Matzura, H. Angew. Chem., Int. Ed. Engl. 1964, 3, 231; (b) Rémond, E.; Tessier, A.; Leroux, F. R.; Bayardon, J.; Jugé, S. Org. Lett. 2010, 12, 1568; (c) Huang, W.; Zhong, C.-H. ACS Omega 2019, 4, 6690; (d) Bugaenko, D. I.; Volkov, A. A.; Livantsov, M. V.; Yurovskaya, M. A.; Karchava, A. V. Chem. Eur. J. 2019, 25, 12502

(22) General procedure for the preparation of diaryl phosphiranium salts 6: To a solution of phosphirane 1 (1 equiv) in 1,1,2,2-tetrachloroethane $(0.1 \mathrm{M})$ were added diphenyliodonium salt (1.2 equiv) copper chloride ( $10 \mathrm{~mol} \%$ ) and copper metal wire (cat.) at room temperature. The reaction mixture was then heated at $50^{\circ} \mathrm{C}$. After cooling down to room temperature, the resulting crude mixture was directly purified by flash column chromatography on silica gel (eluent: $\mathrm{CH}_{2} \mathrm{Cl}_{2}$ then $\mathrm{CH}_{2} \mathrm{Cl}_{2} /$ Acetone $60: 40$ ) to yield the title product 7 . 1-mesityl-1-phenylphosphiranium trifluoromethanesulfonate (7a) Prepared from 1mesitylphosphirane 1a $(0.14 \mathrm{mmol})$ using the general procedure with diphenyliodonium triflate (1.2 equiv). Reaction time: $1 \mathrm{~h}$. The title compound 7a was isolated as a colorless oil ( $42 \mathrm{mg}, 81 \%$ crude yield). $\boldsymbol{R} \boldsymbol{f}=0.40$ (DCM/Acetone: $60 / 40)$; IR (neat) v $1603,1257,1169,1034,636 \mathrm{~cm}^{-1} ;{ }^{1} \mathbf{H}$ NMR (300
$\mathrm{MHz}$, Acetone- $\left.d_{6}, 20^{\circ} \mathrm{C}\right) \delta 7.93-7.82(\mathrm{~m}, 2 \mathrm{H}), 7.81$ $-7.68(\mathrm{~m}, 3 \mathrm{H}), 7.35\left(\mathrm{~d},{ }^{4} J_{H-P}=5.9 \mathrm{~Hz}, 2 \mathrm{H}\right), 3.36-$ $3.23(\mathrm{~m}, 2 \mathrm{H}), 3.08-2.96(\mathrm{~m}, 2 \mathrm{H}), 2.70\left(\mathrm{~d}, \mathrm{~d},{ }^{4} J_{H-P}\right.$ $=1.7 \mathrm{~Hz}, 6 \mathrm{H}), 2.44(\mathrm{~s}, 3 \mathrm{H}) ;{ }^{13} \mathbf{C}$ NMR $(75 \mathrm{MHz}$, Acetone- $\left.d_{6}, 20^{\circ} \mathrm{C}\right) \delta 148.5\left(\mathrm{~d},{ }^{4} J_{C-P}=3.1 \mathrm{~Hz}, \mathrm{Cq}\right)$, $147.1\left(\mathrm{~d},{ }^{2} J_{C-P}=10.7 \mathrm{~Hz}, 2 \mathrm{Cq}\right), 135.8\left(\mathrm{~d},{ }^{4} J_{C-P}=4.5\right.$ $\mathrm{Hz}, \mathrm{CH}), 133.4\left(\mathrm{~d},{ }^{3} J_{C-P}=13.3 \mathrm{~Hz}, 2 \mathrm{CH}\right), 131.6(\mathrm{~d}$, $\left.{ }^{3} J_{C-P}=16.4 \mathrm{~Hz}, 2 \mathrm{CH}\right), 131.1\left(\mathrm{~d},{ }^{2} J_{C-P}=13.4 \mathrm{~Hz}, 2\right.$ $\mathrm{CH}), 122.3\left(\mathrm{q},{ }^{1} J_{C-F}=321.8 \mathrm{~Hz}, \mathrm{CF}_{3}\right), 115.2\left(\mathrm{~d},{ }^{1} J_{C-}\right.$ $P=90.5 \mathrm{~Hz}, \mathrm{Cq}), 109.2\left(\mathrm{~d},{ }^{1} J_{C-P}=97.4 \mathrm{~Hz}, \mathrm{Cq}\right), 22.6$ $\left(\mathrm{d},{ }^{3} J_{C-P}=8.9 \mathrm{~Hz}, 2 \mathrm{CH}_{3}\right), 21.6\left(\mathrm{~d},{ }^{5} J_{C-P}=1.4 \mathrm{~Hz}\right.$, $\left.\mathrm{CH}_{3}\right), 12.9$ (d, $\left.{ }^{1} J_{C-P}=3.2 \mathrm{~Hz}, 2 \underline{\mathrm{CH}_{2}}-\mathrm{P}\right) ;{ }^{31} \mathbf{P}$ NMR $\left(121 \mathrm{MHz}\right.$, Acetone- $\left.d 6,20^{\circ} \mathrm{C}\right) \delta-113.8 ;{ }^{19} \mathbf{F}$ NMR $\left(282 \mathrm{MHz}\right.$, Acetone- $\left.d_{6}, 20^{\circ} \mathrm{C}\right) \delta-78.9$; HRMS (ESI) $\mathrm{m} / \mathrm{z}$ calculated for $\mathrm{C}_{17} \mathrm{H}_{20} \mathrm{P}[\mathrm{M}]^{+}$: 255.1302, found 255.1303 . 